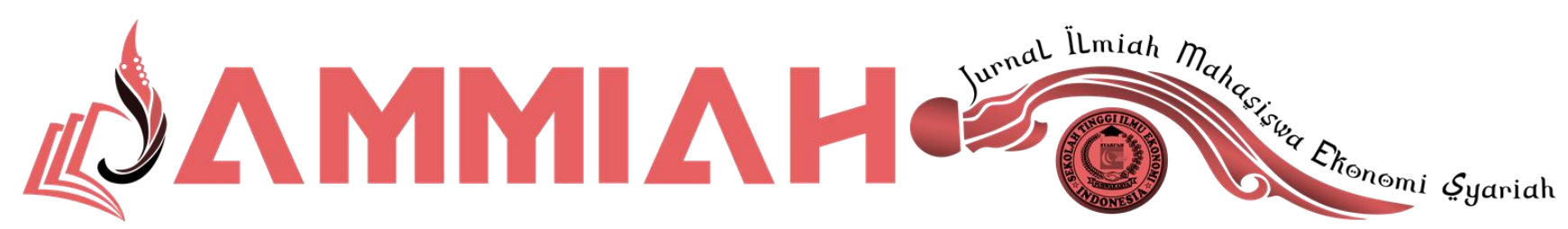

Volume 1 Nomor 2, September 2021

\title{
Sistem Penjualan Di PT. Hae Indo Chemical Cikopo Purwakarta
}

\author{
Mila Aprilianti, Rahma Ngaisah \\ ${ }^{1}$ PT. Hae Indo Chemical Cikopo Purwakarta \\ 1,2Sekolah Tinggi Ilmu Ekonomi Syariah (STIES) Indonesia Purwakarta \\ ${ }^{1}$ milaaprilianti66@gmail.com \\ ${ }^{2}$ rahmangaisah33@gmail.com
}

\begin{abstract}
ABSTRAK
Sistem penjualan merupakan salah satu kegiatan yang sangat penting bagi setiap perusahaan, oleh karena itu diperlukan suatu sistem yang efektif dan efisien untuk membantu peningkatan dan kemajuan perusahaan. Dengan semakin meningkatnya kemajuan perusahaan dalam sistem penjualan akan lebih cepat dan mudah untuk menaikkan laba dan penerimaan kas bertambah sehingga perusahaan akan mendapatkan keuntungan dengan mengurangi kerugian. Tujuan dari penelitian adalah untuk mengetahui system penjualan tunai dan untuk mengatahui penjualan kredit di PT. Hae Indo Chemical Cikopo Purwakarta. Metode penelitian ini menggunakan metode kualitatif deskriptif dengan proses teknik pengumpulan data yang digunakan adalah obsevasi, wawancara, dokumentasi di lapangan. Dalam sistem penjualan di perusahaan ini menggunakan sistem penjualan secara manual atau offline. Seperti proses pembayaran, Pengemasan, Dokumen-dokumen yang diperlukan, Penentuan harga, dan Proses pengiriman. Dengan adanya hasil penelitian ini memungkinkan perusahaan yang baru berjalan 2 tahun ini bisa menjadi perusahaan yang lebih maju dan besar dengan sangat cepat.

Kata kunci : Sistem Penjualan, Tunai, Kredit.
\end{abstract}

\section{ABSTRACT}

The sales system is one of the most important activities for every company, therefore an effective and efficient system is needed to assist the improvement and progress of the company. With the increasing progress of the company in the sales system, it will be faster and easier to

JAMMIAH (Jurnal Ilmiah Mahasiswa Ekonomi Syariah), Volume 1, Nomor 2, September 2021 http://journal.sties-purwakarta.ac.id/index.php/jammiah/ ISSN: 2797-040X (Media Online) 2797-197X (Media Cetak) 
increase profits and increase cash receipts so that the company will benefit by reducing losses. The purpose of this research is to know the cash sales system and to know the credit sales at PT. Hae Indo Chemical Cikopo Purwakarta. This research method uses descriptive qualitative methods with the process of data collection techniques used are observations, interviews, documentation in the field. The sales system in this company uses a manual or offline sales system. Such as payment processing, packaging, required documents, pricing, and shipping process. With the results of this study, it is possible for a company that has only been running for 2 years to become a more advanced and large company very quickly.

Keywords : Sales, Cash, Credit Systems.

\section{PENDAHULUAN}

Sejalan dengan perkembangan dunia usaha, persaingan memang tidak dapat dihindarkan terutama pada perusahaan yang bergerak di bidang usaha yang sejenis. Persaingan menuntut manajemen untuk meningkatkan sistem informasi akuntansi agar tepat guna dan tepat waktu. Salah satu aktivitas yang penting dalam kegiatan perusahaan adalah kegiatan untuk mencari laba yaitu melalui penjualan. ${ }^{1}$ Aktivitas penjualan merupakan salah satu tujuan utama perusahaan setelah memproduksi barang-barangnya. Dalam pandangan islam aktivitas jual beli harus sesuai dengan norma-norma atau hukum-hukum islam yang dimana ketentuan tersebut sudah dijelaskan dalam Al-qur'an dan Hadist yang telah disebutkan dalam surat al-Baqarah ayat 275, dalam isi kandungannya yaitu dalam melakukan aktivitas jual beli diharamkan adanya riba. Aktivitas penjualan dapat dibedakan menjadi dua macam yaitu penjualan tunai dan penjualan kredit.

Penelitian tentang Sistem Penjualan di perusahaan sudah banyak dilakukan oleh peneliti sebelumnya seperti yang dilakukan oleh Henny Hendari, I Gusti Made ${ }^{2}$ Karmawan dan Ferdinandus Penelitian ini bertujuan untuk mengidentifikasi masalah dan kelemahan yang terjadi pada sistem penjualan yang berjalan, merancang aplikasi sebagai solusi untuk mengatasi masalah dan kelemahan yang berhubungan dengan sistem penjualan di perusahaan dagang dalam melakukan transaksi penjualan baik tunai maupun penjualan kredit secara terkomputerisasi, membantu dalam pengadaan laporan penjualan, laporan piutang, juga jurnal penjualan yang akurat dan yang akan digunakan sebagai dokumen dan pembanding setiap bulannya. Penelitian ini hanya membahas tentang perancangan sistem penjualan dengan

${ }^{1}$ Rochmawati Daud and valeria mimosa Windana, "Pengembangan Sistem Informasi Akuntansi Penjualan Dan Penerimaan Kas Berbasis Komputer Pada Perusahaan Kecil Studi Kasus PT Trust Technology," Jurnal Manajemen Dan Bisnis Sriwijaya 12 (2014): 17-28.

${ }^{2}$ Henny Hendari, I Gusti Made Karmawan, and others, “Analisis Dan Perancangan Sistem Informasi Akuntansi Penjualan," PEKBIS (Jurnal Pendidikan Ekonomi Dan Bisnis) 1, no. 03 (2009).

JAMMIAH (Jurnal Ilmiah Mahasiswa Ekonomi Syariah), Volume 1, Nomor 2, September 2021 
menggunakan aplikasi, tidak disertakan hambatan-hambatan apabila aplikasi yang digunakan dalam sistem penjualan mengalami kendala atau tidak dapat dibuka. Selanjutnya penelitian dilakukan oleh Winda Kusuma Wardani ${ }^{3}$ Tujuan penelitian ini adalah untuk mengetahui sistem dan prosedur penjualan dan penerimaan kas dalam mendukung upaya peningkatan pengendalian perusahaan. Tetapi dalam penelitian ini tidak mengkaji secara detail tentang bagaimana proses penjualan yang dilakukan dalam suatu perusahaan dan dalam penelitian ini juga tidak mengkaji perbedaan mengenai dokumen-dokumen yang diperlukan saat melakukan proses penjualan tunai dan penjualan kredit.

Dapat disimpulkan bahwa penelitian sebelumnya banyak yang meneliti tentang sistem penjualan dan prosedur penjualan di perusahan saja. Tidak menjelaskan apa saja langkah-langkah dalam melakukan proses penjualan dalam suatu perusahaan dan perbedaan-perbedaan apa saja yang dilakukan saat terjadinya transaksi penjualan tunai dan penjualan kredit.

Penelitian ini mengkaji lebih dalam terkait sistem penjualan yang ada di perusahaan dalam pandangan islam, termasuk menjelaskan keuntungan melakukan transaksi penjualan suatu perusahaan, langkah-langkah dalam melakukan proses penjualan, perbedaan-perbedaan saat melakukan transaksi penjualan tunai maupun penjualan kredit, kelemahan dan kelebihan transaksi penjualan tunai dan penjualan kredit. Tujuan dari penelitian ini adalah untuk mengetahui sistem penjualan tunai dan penjualan kredit di PT. Hae Indo Chemical Cikopo Purwakarta.

\section{A.Pengertian Penjualan}

\section{II.TINJAUAN PUSTAKA}

Istilah penjualan sering disalah artikan dengan istilah pemasaran, bahkan ironisnya ada yang menganggap sama pengertian penjualan dan pemasaran. Kesalahpahaman tidak hanya pada praktek penjualan tetapi juga pada struktur organisasi perusahaan. Pada hakekatnya kedua istilah tersebut memiliki arti dan ruang lingkup yang berbeda. Pemasaran memiliki arti yang lebih luas meliputi berbagai fungsi perusahaan, sedangkan penjualan merupakan bagian dari kegiatan pemasaran itu sendiri. Dengan demikian penjualan adalah tidak sama dengan pemasaran. ${ }^{4}$

${ }^{3}$ Winda Kusuma Wardani, “Analisis Sistem Dan Prosedur Penjualan Dan Penerimaan Kas Dalam Upaya Meningkatkan Pengendalian Intern Perusahaan (Studi Kasus Pada Pt Anugerah Cendrawasih Sakti Motor Malang)," Jurnal Administrasi Bisnis 12, no. 1 (2014).

${ }^{4}$ Zulkarnain, Ilmu Menjual (Pendekatan Teoritis E Kecakapan Menjual), 1st ed. (Yogyakarta: Graha Ilmu, 2012).

JAMMIAH (Jurnal Ilmiah Mahasiswa Ekonomi Syariah), Volume 1, Nomor 2, September 2021 
Penjualan adalah kegiatan yang terkait proses produksi, finansial, sumber daya manusia, riset dan pengembangan dan seterusnya sehingga tidak mungkin penjualan yang berhasil tidak disinergikan dengan aspek lainnya dalam perusahaan. Penjualan merupakan tujuan dari pemasaran artinya perusahaan melalui departemen/bagian pemasaran termasuk tenaga penjualan (sales force) nya akan berupaya melakukan kegiatan penjualan untuk menghabiskan produk yang dihasilkan.

Arti pentingnya penjualan dalam konteks pemasaran begitu urgen untuk dibicarakan dan didiskusikan karena dapat menentukan keberhasilan dalam kegiatan pemasaran, walaupun fungsi penjualan hanya merupakan salah satu dari kegiatan pemasaran. Keberhasilan dalam program pemasaran sangat ditunjang oleh penjualan. Artinya penjualan memegang posisi sentral untuk meraih keberhasilan. Penjualan diartikan dalam artian positif dan mencapai tujuan yang diinginkan seseorang atau perusahaan. Penjualan yang dilakukan secara positif memberikan efek jangka panjang dan dapat mempertahankan eksistensi usaha dimasa yang akan datang. Dengan demikian penjualan dalam artian ini harus dipertahankan dan dikembangkan secara baik yang dapat dipraktekkan setiap individu atau perusahan dan membawa dampak positif pula terhadap perkembangan usaha. Seorang penjual yang sukses, selalu berpedoman kepada nilai-nilai dan norma-norma yang berlaku agar pembeli tidak merasa tertipu dalam melakukan pembelian.

Melihat perkembangan tata niaga yang begitu pesat akhir-akhir ini posisi wiraniaga atau tenaga penjual menjadi suatu pilihan yang menarik karena dapat menjanjikan keinginan seseorang untuk meraih penghasilan yang relatif tinggi bilamana bekerja disuatu instansi pemerintah atau perusahaan.

Ternyata perdagangan atau jual beli tidak hanya dikenal dalam ekonomi konvensional saja. Akan tetapi perdagangan atau jual beli juga sudah ada dalam agama Islam sejak terdahulu. Menurut bahasa perdagangan atau jual beli berarti alBai', al-Tijarah dan al-Mubadalah, sebagaimana Allah Swt berfirman: ${ }^{5}$

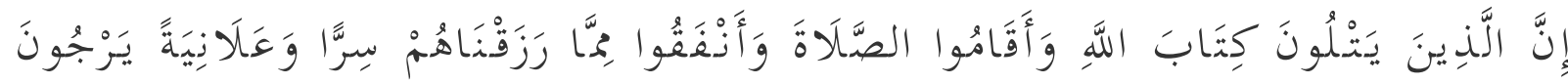

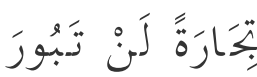

Artinya: "Sesungguhnya orang-orang yang selalu membaca kitab Allah dan mendirikan shalat dan menafkahkan sebahagian dari rezeki yang Kami anugerahkan kepada mereka dengan diam-diam dan terang-terangan, mereka itu mengharapkan perniagaan yang tidak akan merugi," (QS Fathir: 29)6.

${ }^{5}$ Ain Rahmi, “Mekanisme Pasar Dalam Islam," Jurnal Ekonomi Bisnis dan Kewirausahaan Vol. 4, No (2015).

${ }^{6}$ Departemen Agama RI, Al-Qur'an Dan Terjemahnya (Jakarta: PT. Sygma Examedia Arkanlemma, 2009).

JAMMIAH (Jurnal Ilmiah Mahasiswa Ekonomi Syariah), Volume 1, Nomor 2, September 2021 
Menurut istilah (terminologi) yang dimaksud dengan jual beli adalah menukar barang dengan barang atau uang dengan uang dengan jalan melepaskan hak milik dari yang satu kepada yang lain atas dasar saling merelakan. ${ }^{7}$ Perdagangan yang Islami adalah perdagangan yang dilandasi oleh nilainilai dan etika yang bersumber dari nilai-nilai dasar agama yang menjunjung tinggi tentang kejujuran dan keadilan. Muhammad Saw dalam ajarannya meletakkan keadilan dan kejujuran sebagai prinsip dalam perdagangan.

Konteks dari perdagangan adil yang diperintahkan Rasulullah adalah untuk menegakkan kejujuran dalam transaksi serta menciptakan hubungan baik dalam berdagang. Ketidakjujuran dalam perdagangan sangat dilarang oleh Nabi. Bahkan, Beliau menyatakan bahwa perdagangan sebagai suatu hal yang haram, bila keuntungan individu yang diperoleh dari transaksi perdagangan itu akan mendatangkan kerugian dan penderitaan pada beberapa orang lain atau pada masyarakat luas. Untuk menjadi pedagang yang baik, Islam telah mengatur agar persaingan antar pedagang di pasar dilakukan dengan cara yang adil dan jujur. Segala bentuk transaksi yang menimbulkan ketidakadilan serta berakibat terjadinya kecenderungan meningkatnya harga barang-barang secara zalim sangat dilarang oleh Islam. Ada berbagai transaksi perdagangan yang dilarang oleh Rasulullah dalam keadaan pasar normal diantaranya adalah sebagai berikut: ${ }^{8}$

1. Tallaqqi rukban, yaitu mencegat pedagang yang membawa barang dari tempat produksi sebelum sampai di pasar. Rasulullah melarang praktik perdagangan seperti ini dengan tujuan untuk menghindari ketidaktahuan penjual dari daerah pedesaan akan harga barang yang berlaku dikota.

2. Perdagangan yang menipu, Islam sangat melarang segala bentuk penipuan, untuk itu Islam sangat menuntut suatu perdagangan yang dilakukan secara jujur dan amanah.

3. Perdagangan najasy, yaitu parktik perdagangan di mana seseorang berpurapura sebagai pembeli yang menawar tinggi harga barang

4. dagangan disertai memuji-muji kualitas barang tersebut secara tidak wajar, tujuannya adalah untuk menaikkan harga barang.

5. Memperdagangkan barang haram, yaitu memperjualbelikan barangbarang yang telah dilarang dan diharamkan oleh Alquran, seperti daging babi, darah, minuman keras, dan bangkai.

7 Wati Susiawati, “Jual Beli Dan Dalam Konteks Kekinian," Jurnal Ekonomi Islam 8, no. 02 (2017): 171-184.

${ }^{8}$ Heru Cahyono, "Konsep Pasar Syariah Dalam Perspektif Etika Bisnis Islam," Ecobankers: Journal of Economy and Banking 1, no. 2 (2020): 14-27.

JAMMIAH (Jurnal Ilmiah Mahasiswa Ekonomi Syariah), Volume 1, Nomor 2, September 2021 
6. Perdagangan secara riba, yaitu pengambilan tambahan dalam transaksi jual beli ataupun pinjam-meminjam yang berlangsung secara zalim dan bertentangan dengan prinsip mu'amalah secara Islam. Allah berfirman dalam surat Al-baqarah : 275.

$$
\text { وَأَحَلَّ اللَّهُ الْبَنْيْعَ وَحَرَّمَ الرِّبَا }
$$

Artinya: "Dan Allah Telah menghalalkan jual beli dan mengharamkan riba”.(QS Al-Baqarah: 275) ${ }^{9}$.

\section{B. Konsep Penjualan}

Konsep ini menjelaskan bahwa sudah banyak produsen yang menawarkan berbagai variasi produk dipasaran. Konsumen mempunyai banyak pilihan, dan mereka dengan mudah memilih produsen yang berbeda. Dengan situasi seperti ini, pemasar tidak akan berhasil memasarkan produknya jika tidak mempunyai usaha mempromosikan barang dan penjualan. Jika penjualan tidak agresif, konsumen tidak akan bergeming. Hal yang kurang dalam hal ini adalah transaksi menjadi tujuan. Setelah transaksi terjadi, perusahaan sering kali tidak memerhatikan konsumen lagi.

Konsep penjualan mempunyai perspektif dari dalam ke luar. Konsep penjualan dimulai dari kesadaran tentang "apa yang bisa aku dibuat", kemudian dikembangkan dengan bagaimana mempromosikannya sehingga produk yang bisa kita buat itu dapat kita jual sehingga mendapat laba melalui volume penjualan. Konsep ini menafikan kepuasan konsumen. Yang penting produk/barang kita laku, dan kita mendapat laba. Seperti terlihat dalam gambar dibawah ini. ${ }^{10}$

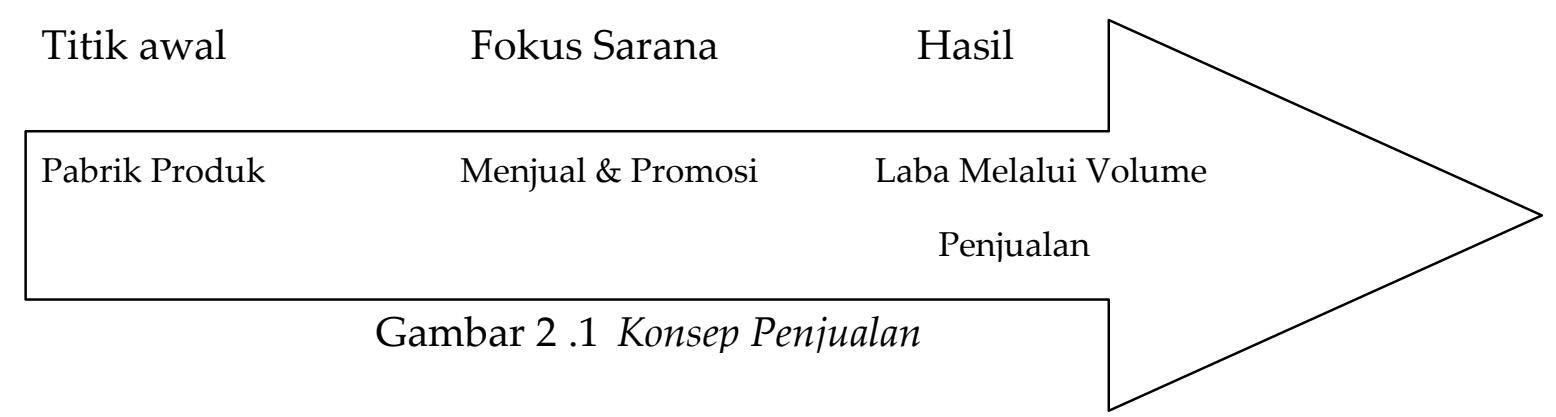

Kebanyakan perusahaan mempraktikkan konsep penjualan ketika mereka memiliki kapasitas berlebih. Tujuan mereka adalah menjual apa yang mereka buat dan bukannya membuat apa yang diinginkan dipasar. Akan tetapi, pemasaran yang berbasis pada penjualan agresif membawa risiko yang tinggi. Ia mengandaikan bahwa pelanggan yang dibujuk untuk membeli sebuah produk akan menyukainya

${ }^{9}$ Soenarjo, Al-Qur'an Dan Terjemahnya (Jakarta: Serajaya Sentra, 1987), 189.

10 Sentot Imam Wahjono, Manajemen Pemasaran Bank (Yogyakarta: Graha Ilmu, 2010), 3.

JAMMIAH (Jurnal Ilmiah Mahasiswa Ekonomi Syariah), Volume 1, Nomor 2, September 2021 
dan jika mereka tidak suka, mereka tidak akan mengembalikannya atau menjelekjelekkannya atau mengadu ke organisasi konsumen, atau bahkan mungkin membelinya lagi. ${ }^{11}$

Konsep menjual yang baik dan benar bisa disingkat dalam $5 \mathrm{H}$, yaitu:

1) Hear what he says, dengarkan keluhan yang dia sampaikan.

2) Touch the heart, sentuh "feel" nya, emosinya dan egonya.

3) Help him/her, bantu dirinya untuk merasakan produk anda.

4) Make him happy, buat dirinya senang berhubungan dengan anda.

5) Hand in hand (bergandengan tangan) buatlah calon pelanggan yang telah menjadi pelanggan anda, senang membeli produknya karena profesionalisme.

Marketing Mix merupakan strategi kombinasi yang dilakukan oleh berbagai perusahaan dalam bidang pemasaran. Hampir semua perusahaan melakukan strategi ini guna mencapai tujuan pemasarannya, apalagi dalam kondisi persaingan yang demikian ketat saat ini. Kombinasi yang terdapat dalam komponen marketing mix harus dilakukan secara terpadu. Artinya, pelaksanaan dan penerapan komponen ini harus dilakukan dengan memerhatikan antara satu komponen dengan komponen lainnya.

Kotler menyebutkan konsep bauran pemasaraan (Marketing Mix) terdiri dari empat P (4P), yaitu: Product (produk), Price (harga), Place (tempat/saluran distribusi), Promotion (promosi). ${ }^{12}$ Dalam hal ini bauran pemasaran yang akan penulis jelaskan yaitu terdiri dari segala hal yang biasa dilakukan perusahaan untuk mempengaruhi permintaan atas produknya. Beberapa kemungkinan itu bisa dikumpulkan ke dalam empat kelompok variabel yang dikenal sebagai "empat P", yaitu: produk (product), harga (price), tempat (place) dan promosi (promotion).

\section{Produk}

Produk menurut Kotler dan Amstrong adalah segala sesuatu yang ditawarkan ke pasar untuk mendapatkan perhatian, dibeli, dipergunakan, dan yang dapat memuaskan keinginan atau kebutuhan konsumen. Berasal dari kata product yang berarti hasil. Produk adalah suatu sifat yang kompleks, baik yang dapat diraba maupun yang tidak dapat diraba, termasuk kemasan, harga, prestise perusahaan, dan pelayanan jasa kebutuhannya. Produk kemudian diklasifikasikan menjadi dua, yakni

${ }^{11}$ Philip Kotler and Kevin Lane Keller, Manajemen Pemasaran, Jilid 2 Ed. (Jakarta: Erlangga, 2009).

12 Yenny Kuratul Aini and Wadhan Wadhan, "Pengaruh Strategi Bauran Pemasaran Terhadap Peningkatan Loyalitas Nasabah Pada BPRS Bhakti Sumekar Kantor Cabang Pamekasan," IQTISHADIA: Jurnal Ekonomi dan Perbankan Syariah 3, no. 2 (2016): 278-289.

JAMMIAH (Jurnal Ilmiah Mahasiswa Ekonomi Syariah), Volume 1, Nomor 2, September 2021 
jasa dan barang yang memang memiliki perbedaan besar, yang satu dapat dilihat dan diraba (tangible) sementara yang satu lagi hanya dirasakan (intangible). ${ }^{13}$

Menurut Islam, produk konsumen adalah berdayaguna, materi yang dapat dikonsumsi yang bermanfaat yang bernilai guna yang menghasilkan perbaikan material, moral, spiritual bagi konsumen. Produk meliputi kualitas, keistimewaan, desain, gaya, keanekaragaman, bentuk, merek, kemasaan, ukuran, pelayanan, jaminan dan pengembalian. ${ }^{14}$

Produk yang ditawarkan pada konsumen tersebut dapat berbentuk barang fisik (mobil, TV, rumah dan lainnya), jasa (hotel, transportasi, asuransi dll), orang atau pribadi (Leonal Messi, Lady Gaga, dll), tempat (pantai Kuta Bali, Senggigi, Candi Borobudur, dll), Organisasi (PMI, Ikatan Dokter Indonesia, dll), dan ide (Kredit Usaha Rakyat, Keluarga Berencana, dll). ${ }^{15}$

Dalam merancang penawaran atau produk, pemasar perlu memahami lima tingkatan produk yaitu:

1) Produk utama/inti (core benefit), yaitu manfaat yang sebenarnya dibutuhkan dan akan dikonsumsi oleh pelanggan dari setiap produk.

2) Produk genetik, yaitu produk dasar yang mampu memenuhi fungsi produk yang paling dasar (rancangan produk minimal agar dapat berfungsi).

3) Produk harapan (expected product), yaitu produk formal yang ditawarkan dengan berbagai atribut dan kondisinya secara normal (layak) diharapkan dan disepakati untuk dibeli.

4) Produk pelengkap (augmented product), yakni berbagai atribut produk yang dilengkapi atau ditambahi berbagai manfaat dan layanan, sehingga dapat memberikan tambahan kepuasan dan bisa dibedakan dengan produk pesaing.

5) Produk potensial, yaitu segala macam tambahan dan perubahan yang mungkin dikembangkan untuk suatu produk dimasa mendatang. ${ }^{16}$

Pengelolaan strategi siklus hidup didasarkan kepada keempat tahapan siklus hidup produk, yakni:

1) Strategi Pemasaran Tahapan Perkenalan

Dalam meluncurkan produk baru, manajemen pemasaran dapat membentuk suatu tingkat tinggi atau rendah bagi setiap variabel pemasaran seperti harga, promosi, distribusi dan mutu produk.

2) Pemasaran Tahap Pertumbuhan

${ }^{13}$ Arif Rahman, Strategi Dahsyat Marketing Mix for Small Business (Jakarta: Transmedia Pustaka, 2010), 9.

${ }^{14}$ Muhammad Suyanto, Muhammad Business Strategy and Ethics (Yogyakarta: Andi Offset, 2008), 263.

${ }^{15}$ Zulkarnain, Ilmu Menjual (Pendekatan Teoritis \& Kecakapan Menjual), 86.

${ }^{16}$ Fandy Tjiptono, Strategi Pemasaran (Yogyakarta: Andi, 2000), 96.

JAMMIAH (Jurnal Ilmiah Mahasiswa Ekonomi Syariah), Volume 1, Nomor 2, September 2021 
Tahap ini ditandai dengan adanya peningkatan penjualan. Konsumen awal merasa senang dan konsumen berikutnya mulai membeli. Pesaing baru mulai memasuki pasar, harga bertahan atau sedikit turun, dan laba meningkat. Sepanjang tahap pertumbuhan, perusahaan dapat menggunakan beberapa strategi untuk mempertahankan pertumbuhan pasar selama mungkin:

a) Meningkatkan kualitas produk, menambah ciri-ciri atau fitur-fitur produk, serta memperbaiki modelnya.

b) Menambah model baru dan produk penyerta.

c) Memasuki segmen pasar baru.

d) Meningkatkan cakupan dan memasuki saluran distribusi baru.

e) Beralih dari iklan yang membuat orang menyadari produk ke iklan yang membuat orang memilih produk tertentu

f) Menurunkan harga untuk menarik lapisan berikutnya yang sensitif terhadap harga.

3) Startegi Pemasaran Tahap Kedewasaan

Pada suatu titik, tingkat pertumbuhan penjualan produk akan menurun dan produk akan memasuki tahap kedewasaan relatif. Hal ini biasanya berlangsung lebih lama dari tahap sebelumnya dan merupakan tantangan berat bagi manajer pemasaran. Kebanyakan produk berada pada tahap kedewasaan dari siklus hidup.

4) Strategi Tahap Penurunan

Penurunan bisa cepat atau lambat, karena alasan teknologi, pergeseran selera konsumen, dan meningkatnya persaingan. Mempertahankan produk adalah beban bagi perusahaan maupun karyawan. Strategi bertahan dalam tahap penurunan yang tersedia untuk perusahaan yaitu:

a) Meningkatkan investasi perusahaan untuk mendominasi atau memperkuat posisi pasar.

b) Mempertahankan level investasi sampai ketidakpastian industri. ${ }^{17}$

Atribut produk adalah unsur-unsur produk yang dipandang penting oleh konsumen dan dijadikan dasar pengambilan keputusan pembelian. Atribut produk meliputi merek, kemasan, jaminan (garansi), pelayanan, dan sebagainya.

\section{a. Merek}

Merek merupakan nama, istilah, tanda, simbol/lambang, desain, warna, gerak, atau kombinasi atribut-atribut produk lainnya yang diharapkan dapat

${ }_{17}$ Nurahmi Hayani, “Manajemen Pemasaran Bagi Pendidikan Ekonomi” (Pekanbaru: Suska Press, 2012), 96.

JAMMIAH (Jurnal Ilmiah Mahasiswa Ekonomi Syariah), Volume 1, Nomor 2, September 2021 
memberikan identitas dan diferensiasi terhadap produk pesaing. Pada dasarnya suatu merek juga merupakan janji penjual untuk secara konsisten menyampaikan serangkaian ciri-ciri, manfaat, dan jasa tertentu kepada para pembeli. Merek yang baik juga menyampaikan jaminan tambahan berupa jaminan kualitas. Merek sendiri digunakan untuk beberapa tujuan, yaitu:

1) Sebagai identitas, yang bermanfaat dalam diferensiasi atau membedakan produk suatu perusahaan dengan produk pesaingnya. Ini akan memudahkan konsumen untuk mengenalinya saat berbelanja dan saat melakukan pembelian ulang.

2) Alat promosi, yaitu sebagai daya tarik produk.

3) Untuk membina citra, yaitu dengan memberikan keyakinan, jaminan kualitas, serta prestise tertentu kepada konsumen.

4) Untuk mengendalikan pasar. ${ }^{18}$

Menurut seorang eksekutif pemasaran, merek dapat menyampaikan empat tingkat arti:

1) Atribut. Merek pertama-tama akan mengingatkan orang pada atribut tertentu. Mercedes membawa atribut seperti "diperlengkapi mesin bagus", "dibuat dengan bahan bermutu tinggi", "awet", "bergengsi tinggi", "cepat", "mahal", dan "nilai jual tinggi".

2) Manfaat. Pelanggan tidak membeli atribut, mereka membeli manfaat. Oleh karena itu, atribut harus diterjemahkan menjadi manfaat fungsional dan emosional. Atribut "dibuat dengan bahan bermutu tinggi" mungkin diterjemahkan menjadi manfaat fungsional dan emosional "saya merasa aman sekalipun terjadi kecelakaan".

3) Nilai. Merek juga mencerminkan sesuatu mengenai nilai-nilai pembeli. Jadi, pembeli mercedes menilai prestasi, keamanan, dan prestise tinggi. Pemasar merek harus mengenali kelompok spesifik pembeli mobil yang nilai-nilainya sesuai dengan paket manfaat yang disampaikan.

4) Kepribadian. Merek juga menggambarkan kepribadian. Peneliti motivasi kadang-kadang bertanya, "bila merek ini adalah manusia, seperti apa gambarnya?" konsumen mungkin membayangkan sebuah mobil mercedes sebagai seorang eksekutif bisnis berusia pertengahan yang kaya. Merek akan menarik orang yang gambaran sebenarnya dan citra dirinya cocok dengan citra merek. ${ }^{19}$

18 Tjiptono, Strategi Pemasaran, 104.

${ }^{19}$ Francis Tantri and Thamrin Abdullah, Manajemen Pemasaran (Jakarta: PT. Raja Grafindo Persada, 2019), 161.

JAMMIAH (Jurnal Ilmiah Mahasiswa Ekonomi Syariah), Volume 1, Nomor 2, September 2021 http://journal.sties-purwakarta.ac.id/index.php/jammiah/ ISSN: 2797-040X (Media Online) 2797-197X (Media Cetak) 
Perusahaan harus memutuskan bagaimana suatu merek dapat menerangkan sebuah nama merek pada produknya. Pemberian merek menjadi sangat penting sehingga jarang ditemukan barang yang tidak bermerek. Manfaat merek bagi distributor:

1) Sebagai cara untuk memudahkan penanganan produk.

2) Mengidentifikasi dalam pendistribusian produk.

3) Meminta produksi agar berada pada standar mutu tertentu.

4) Meningkatkan pilihan para pembeli. ${ }^{20}$

\section{b. Kemasan}

Pengemasan (packaging) merupakan proses yang berkaitan dengan perancangan dan pembuatan wadah (container) atau pembungkus (wrapper) untuk suatu produk. Pemberian kemasan pada suatu produk bisa memberikan tiga manfaat utama, yaitu manfaat komunikasi, manfaat fungsional dan manfaat perseptual:

1) Manfaat Komunikasi

Manfaat utama kemasan adalah sebagai media pengungkapan informasi produk kepada konsumen. Informasi tersebut meliputi cara menggunakan produk, komposisi produk, dan informasi khusus (efek samping, frekuensi pemakaian yang optimal dan sebagainya).

2) Manfaat Fungsional

Kemasan seringkali pula memastikan peranan fungsional yang penting seperti memberikan kemudahan, perlindungan, dan penyampaian.

3) Manfaat Perseptual

Kemasan juga bermanfaat dalam menanamkan persepsi tertentu dalam benak konsumen. Air mineral seperti Aqua diberi kemasan yang berwarna biru muda untuk memberikan persepsi bahwa produknya segar dan sehat.

Selain itu dewasa ini umumnya kemasan mencantumkan barcode yang antara lain berguna untuk kasir di tempat penjualan dalam mengenali informasi produk tersebut berikut harganya. Etika bisnis dalam hal label ini adalah adanya tuntutan untuk mencantumkan keterangan yang benar dan akurat. $^{21}$

\section{c. Pemberian Label (Labelling)}

Labelling berkaitan erat dengan pengemasan. Label merupakan bagian dari suatu produk yang menyampaikan informasi mengenai produk dan penjual.

${ }^{20}$ Freddy Rangkuti, Strategi Promosi Yang Kreatif \& Analisis Kasus Integrated Marketing Communication (Jakarta: Gramedia Pustaka Utama, 2009), 81.

${ }^{21}$ Muhandis Natadiwirya, Etika Bisnis Islam (Jakarta: Granada Press, 2007), 85.

JAMMIAH (Jurnal Ilmiah Mahasiswa Ekonomi Syariah), Volume 1, Nomor 2, September 2021 
Sebuah label bisa merupakan bagian dari kemasan, atau bisa pula merupakan etiket (tanda pengenal) yang dicantelkan pada produk. Dengan demikian, ada hubungan erat antara labelling, packaging, dan branding. Secara garis besar terdapat tiga macam label, yaitu:

1) Brand label, yaitu nama merek yang diberikan pada produk atau dicantumkan pada kemasan.

2) Descriptive label, yaitu label yang memberikan informasi obyektif mengenai penggunaan, kontruksi/pembuatan, perawatan/perhatian dan kinerja produk, serta karakteristik-karakteristik lainnya yang berhubungan dengan produk.

3) Grade label, yaitu label yang mengidentifikasi penilaian kualitas produk (Product's judged quality) dengan huruf, angka atau kata.

\section{d. Jaminan (Garansi)}

Jaminan adalah janji yang merupakan kewajiban produsen atas produknya kepada konsumen, di mana para konsumen akan diberi ganti rugi bila produk ternyata tidak bisa berfungsi sebagaimana yang diharapkan atau dijanjikan. Jaminan bisa meliputi kualitas produk, reparasi, ganti rugi (uang kembali atau produk ditukar). ${ }^{22}$

\section{Harga}

Dalam teori ekonomi, kita mempelajari harga (price), nilai (value) dan manfaat (utility) merupakan konsep yang saling berkaitan. Manfaat (utility) adalah atribut sebuah item/barang yang mempunyai kemampuan untuk memuaskan keinginan. Nilai adalah ukuran kuantitatif bobot sebuah produk yang dapat dipertukarkan dengan produk lain. Harga adalah nilai yang disebutkan dalam rupiah dan sen atau medium moneter lainnya sebagai alat tukar. Secara singkat, harga adalah sejumlah uang (kemungkinan ditambah beberapa barang) yang dibutuhkan untuk memperoleh beberapa kombinasi sebuah produk dan pelayanan yang menyertainya. ${ }^{23}$

Ada beberapa faktor yang perlu dipertimbangkan dalam penetapan harga yakni:

a. Faktor internal perusahan yang meliputi tujuan pemasaran perusahaan, strategi bauran pemasaran dan biaya, dan organisasi.

b. Faktor lingkungan eksternal yang meliputi sifat pasar dan permintaan, persaingan dan lingkungan eksternal lainnya. ${ }^{24}$

Penetapan harga memiliki beberapa tujuan:

22 Tjiptono, Strategi Pemasaran, 108.

${ }^{23}$ William J Stanton, Prinsip Pemasaran (Jakarta: Erlangga, 2001), 307.

${ }^{24}$ Zulkarnain, Ilmu Menjual (Pendekatan Teoritis \& Kecakapan Menjual), 94.

JAMMIAH (Jurnal Ilmiah Mahasiswa Ekonomi Syariah), Volume 1, Nomor 2, September 2021 
a. Pembentukan citra seperti sebagai market leader yang mampu menentukan price leader

b. Percepatan penjualan

c. Promosi

d. Perlindungan atas ancaman pesaing yang kerap memainkan harga, meningkatkan daya saing melalui "miring" dan lain-lain. ${ }^{25}$

Harga tidak lagi menjadi faktor yang berpengaruh, selama kebutuhan yang diinginkan pelanggan mampu ter-cover oleh produk yang hendak dimilikinya. Strategi penetapan harga yang sesuai dengan nilai ini adalah sebagai berikut:

a. Prestige price, menawarkan harga yang tinggi untuk produk prestisius berkualitas tinggi.

b. Skimming price, menetapkan harga tinggi untuk produk baru yang kehadirannya didukung oleh dana yang besar untuk promosi. ${ }^{26}$

\section{Tempat}

Place bisa berarti dua hal. Pertama tempat berjualan dan kedua saluran distribusi. Lebih spesifik bisa diartikan display. Yaitu usaha pemajangan produk di suatu wilayah atau toko. ${ }^{27}$ Secara garis besar tempat bauran pemasaran sering juga disebut distribusi. Distribusi adalah kegiatan pemasaran yang berusaha memperlancar dan mempermudah penyampaian barang dan jasa dari produsen kepada konsumen, sehingga penggunaannya sesuai dengan yang diperlukan (jenis, jumlah, harga dan saat dibutuhkan). ${ }^{28}$

Sebagai salah satu variabel marketing mix, place/distribusi mempunyai peranan yang sangat penting dalam membantu perusahaan memastikan produknya, karena tujuan dari distribusi adalah menyediakan barang dan jasa yang dibutuhkan dan diinginkan oleh konsumen pada waktu dan tempat yang tepat. ${ }^{29}$

Kegiatan distribusi dalam Islam ada dua orientasi, pertama adalah menyalurkan rezeki (harta kekayaan) untuk diinfakkan (didistribusikan) demi kepentingan diri sendiri maupun orang lain, seperti pengeluaran zakat sebagai pensucian harta maupun jiwa serta mendermakan sebagian harta bendanya. Kedua, berkenaan dengan mempertukarkan hasil-hasil produksi dan daya ciptanya kepada orang lain

${ }^{25}$ Syihabudhin Sopiah, Manajemen Bisnis Ritel (Yogyakarta: Penerbit Andi, 2008), 146.

${ }^{26}$ Rahman, Strategi Dahsyat Marketing Mix for Small Business, 85.

27 Ali Arifin, “Seni Menjual (Perspektif Bisnis, Ide-Ide Penjualan Serta Strategi Pemasaran)," Penerbit Andi, Yogyakarta (2005), 44.

28 Tjiptono, Strategi Pemasaran, 185.

29 Susanti Aprillia Cahyono, Bramantya Bramantya, and Ryan Sutanto, "Perancangan Promosi Amelia Cake \& Bakery Di Surabaya," Jurnal DKV Adiwarna 1, no. 6 (2015): 12.

JAMMIAH (Jurnal Ilmiah Mahasiswa Ekonomi Syariah), Volume 1, Nomor 2, September 2021 
yang membutuhkan, agar mendapat laba sebagai wujud dari pemenuhan kebutuhan atas bisnis oriented. ${ }^{30}$

Fungsi distribusi adalah untuk mencapai keseimbangan ekonomi (economi equilibrium), meskipun negara merupakan big market (pasar besar). Disisi lain distribusi tidak lepas dari sistem produksi dan konsumsi dalam saluran atas pemasarannya terhadap barang-barang tersebut. Sebagaimana dijelaskan pada gambar berikut ini:

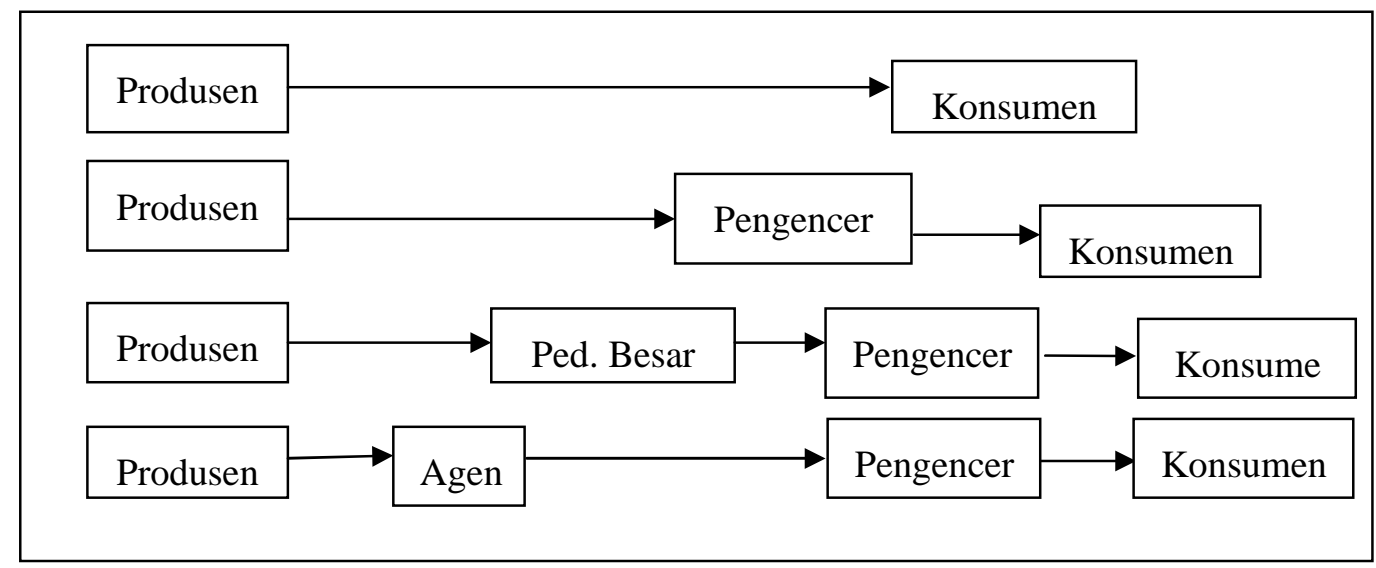

Gambar 2.2

Fungsi Distribusi

a. Produsen - Konsumen

Dikatakan saluran langsung atau saluran nol tingkat (zero level channel) yaitu dari produsen langsung dijual konsumen, tanpa melibatkan pedagang perantara. Hal ini bisa dilakukan dengan cara penjualan pribadi (door to door) melalui pos dari toko milik produsen sendiri.

b. Produsen - Pengencer - Konsumen

Disebut saluran satu tingkat (one level channel) adalah saluran yang sudah menggunakan perantara. Dalam pasar konsumsi, perantara ini adalah pengencer. Perantara pengencer disini adalah membeli dalam jumlah besar ke produsen kemudian dijual eceran kepada konsumen. 3) Produsen Pedagang Besar - Pengencer - Konsumen

Sering disebut saluran dua tingkat (two level channel) yaitu mencakup dua perantara. Dalam hal ini perantara tersebut adalah pedagang besar dan pengencer. Produsen hanya melayani pembeli dalam jumlah yang besar yaitu oleh pedagang besar, kemudian pedagang besar menjual lagi ke pengencer, baru kemudian ke konsumen. Saluran ini sering pula disebut saluran tradisional.

c. Produsen - Agen - Pengencer - Konsumen

30 Abdul Aziz, Ekonomi Islam: Analisis Mikro Dan Makro (Tangerang: Graha Ilmu, 2008), 88.

JAMMIAH (Jurnal Ilmiah Mahasiswa Ekonomi Syariah), Volume 1, Nomor 2, September 2021 
Tipe saluran ini hampir sama dengan tipe yang ketiga diatas, juga melibatkan dua perantara. Hanya saja disini bertindak sebagai pedagang besar yang dipilih oleh produsen. Sasaran penjualan agen di sini terutama ditujukan kepada pengencer besar.

d. Produsen - Agen - Pedagang Besar - Pengencer - Konsumen

Di sini terdapat tiga perantara (three level channel) atau disebut saluran tiga tingkat. Dari agen yang dipilih perusahan masih melalui pedagang besar terlebih dahulu sebelum pengencer.

Penyaluran model di atas tersebut merupakan fungsi distribusi yang berlaku di dunia marketing dalam bisnis. Akan tetapi sekali lagi, fungsi distribusi demikian hanyalah sebatas pemenuhan kebutuhan bagi produsen untuk konsumen dan sejenisnya. Manfaat dari saluran distribusi seperti ini jelas dapat menguntungkan pihak-pihak yang terlibat saja, namun bagi orang yang diluar itu tentu tidak ada manfaatnya. ${ }^{31}$

\section{Promosi}

Promosi merupakan salah satu faktor penentu keberhasilan suatu program pemasaran. Betapapun berkualitasnya suatu produk, bila konsumen belum pernah mendengarnya dan tidak yakin bahwa produk itu akan berguna bagi mereka, maka mereka tidak akan pernah membelinya. ${ }^{32}$

Salah satu fungsi promosi adalah sebagai komunikasi antara dunia usaha dengan masyarakat. Salah satu unsur yang membentuk komunikasi adalah pesan (massage). Pesan ini disampaikan oleh dunia usaha kepada masyarakat. Pesan diharapkan memperoleh respon dan dapat menggugah perhatian (attention) dan menarik minat (interest). Selanjutnya diharapkan adanya keinginan (desire) dan tindakan (action). ${ }^{33}$

Promosi yang dilakukan Rasulullah SAW lebih menekankan pada hubungan dengan pelanggan, meliputi berpenampilan menawan, membangun relasi, mengutamakan keberkahan, memahami pelanggan, mendapat kepercayaan, memberikan pelayanan hebat, berkomunikasi, menjalin hubungan yang bersifat pribadi, tanggap terhadap permasalahan, menciptakan perasaan satu komunitas, berintegrasi, menciptakan keterlibatan dan menawarkan pilihan. ${ }^{34}$

Elemen-elemen promosi tersebut sering disebut dengan bauran promosi yang didalamnya terdiri dari: Iklan (Advertising), Penjualan Perseorangan (personal

${ }^{31}$ Ibid., 91.

32 Tjiptono, Strategi Pemasaran, 129.

${ }_{33}$ Natadiwirya, Etika Bisnis Islam, 86.

${ }^{34}$ Suyanto, Muhammad Business Strategy and Ethics, 273.

JAMMIAH (Jurnal Ilmiah Mahasiswa Ekonomi Syariah), Volume 1, Nomor 2, September 2021 http://journal.sties-purwakarta.ac.id/index.php/jammiah/ ISSN: 2797-040X (Media Online) 2797-197X (Media Cetak) 
selling), Promosi Penjualan (sales promotion), dan publisitas (publicity). Untuk lebih jelasnya keempat macam alat promosi tersebut oleh beberapa penulis diuraikan sebagai berikut: ${ }^{35}$

a. Advertising merupakan suatu bentuk komunikasi pemasaran dari produsen ke konsumen melalui media komunikasi massa, misalnya radio, surat kabar, majalah dan sebagainya. Sehingga advertising merupakan sifat nonpersonal dan merupakan suatu alat untuk mempromosikan produk atau jasa tanpa mengadakan kontak langsung serta si pemasang iklan harus membayar dengan tarif tertentu yang berlaku.

b. Personal selling suatu penyajian secara lisan dan tatap muka di hadapan satu calon pembeli atau lebih dengan tujuan untuk menjual suatu barang.

c. Menurut William J. Stanton promosi penjualan adalah "kegiatan-kegiatan di luar penjualan perseorangan, periklanan dan publisitas yang menstimulasi pembelian oleh konsumen dan keefektifan dealer, misalnya pameran, pertunjukan, demonstrasi serta berbagai kegiatan penjualan luar biasa yang bukan kerja rutin biasa".

d. Publisitas merupakan pelengkap yang efektif bagi alat promosi yang lain seperti periklanan, personal selling, dan promosi penjualan. Biasanya, media bersedia mempublisitaskan suatu cerita apabila materinya dirasakan cukup menarik atau patut dijadikan berita.

Di dalam mekanisme penjualan barang ada kebiasaan yang baik untuk memberikan insentif yang layak atas pembelian yang bersifat khusus antara lain berupa potongan harga, hadiah barang atau hadiah selain barang. Ini adalah promosi juga yang dikenal dengan istilah promosi penjualan. Secara Islami, etika yang harus dijaga adalah jangan sampai ada kebohongan atau penipuan dalam skim pemberian insentif tersebut. ${ }^{36}$

\section{Faktor-faktor yang Mempengaruhi Penjualan}

Dalam praktek, kegiatan penjualan itu dipengaruhi oleh beberapa faktor sebagai berikut:

1. Kondisi dan kemampuan penjual

Transaksi jual-beli atau pemindahan hak milik secara komersial atas barang dan jasa itu pada prinsipnya melibatkan dua pihak, yaitu penjual sebagai pihak pertama dan pembeli sebagai pihak kedua. Disini penjual harus dapat menyakinkan kepada pembelinya agar dapat berhasil mencapai sasaran

${ }^{35}$ Marius P Angipora, Dasar-Dasar Pemasaran (Jakarta: PT. Raja Grafindo Persada, 2002), 344.

${ }^{36}$ Natadiwirya, Etika Bisnis Islam, 87.

JAMMIAH (Jurnal Ilmiah Mahasiswa Ekonomi Syariah), Volume 1, Nomor 2, September 2021 http://journal.sties-purwakarta.ac.id/index.php/jammiah/ ISSN: 2797-040X (Media Online) 2797-197X (Media Cetak) 
penjualan yang diharapkan. Untuk maksud tersebut penjual harus memahami beberapa masalah penting yang sangat berkaitan, yakni:

a. Jenis dan karakteristik barang yang di tawarkan.

b. Harga produk.

c. Syarat penjualan seperti: pembayaran, penghantaran, pelayanan sesudah penjualan, garansi dan sebagainya.

2. Kondisi pasar

Pasar, sebagai kelompok pembeli atau pihak yang menjadi sasaran dalam penjualan, dapat pula mempengaruhi kegiatan penjualannya.

Adapun faktor-faktor kondisi pasar yang perlu diperhatikan adalah:

a. Jenis pasarnya

b. Kelompok pembeli atau segmen pasarnya

c. Daya belinya

d. Frekuensi pembelian

e. Keinginan dan kebutuhan

3. Modal

Akan lebih sulit bagi penjualan barangnya apabila barang yang dijual tersebut belum dikenal oleh calon pembeli, atau apabila lokasi pembeli jauh dari tempat penjual. Dalam keadaan seperti ini, penjual harus memperkenalkan dulu membawa barangnya ketempat pembeli. Untuk melaksanakan maksud tersebut diperlukan adanya sarana serta usaha, seperti: alat transport, tempat peragaan baik didalam perusahaan maupun di luar perusahaan, usaha promosi, dan sebagainya. Semua ini hanya dapat dilakukan apabila penjualan memiliki sejumlah modal yang diperlukan untuk itu.

4. Kondisi organisasi perusahaan

Pada perusahaan besar, biasanya masalah penjualan ini ditangani oleh bagian tersendiri (bagian penjualan) yang dipegang orang-orang tertentu/ahli di bidang penjualan.

5. Faktor lain

Faktor-faktor lain, seperti: periklanan, peragaan, kampanye, pemberian hadiah, sering mempengaruhi penjualan. Namun untuk melaksanakannya, diperlukan sejumlah dana yang tidak sedikit. Bagi perusahaan yang bermodal kuat, kegiatan ini secara rutin dapat dilakukan. Sedangkan bagi perusahaan kecil yang mempunyai modal relatif kecil, kegiatan ini lebih jarang dilakukan.

Ada pengusaha yang berpegangan pada suatu prinsip bahwa "paling penting membuat barang yang baik". Bilamana prinsip tersebut dilaksanakan, maka diharapkan pembeli akan kembali membeli lagi barang yang sama. Namun, sebelum

JAMMIAH (Jurnal Ilmiah Mahasiswa Ekonomi Syariah), Volume 1, Nomor 2, September 2021 
pembelian dilakukan, sering pembeli harus dirangsang daya tariknya, misalnya dengan memberikan bungkus yang menarik atau dengan cara promosi lainnya. ${ }^{37}$

\section{D.Kegiatan Penjualan Dalam Pandangan Ekonomi Islam}

Islam memang mendorong pemeluknya untuk mencari rezeki yang berkah, mendorong berproduksi, dan menekuni aktivitas ekonomi di berbagai bidang usaha, seperti pertanian, perkebunan, industri, perdagangan, dan bidang-bidang usaha lainnya. Islam mendorong setiap amal perbuatan hendaknya menghasilkan produk atau jasa tertentu yang bermanfaat bagi umat manusia, atau memperindah kehidupan, mendatangkan kemakmuran dan kesejahteraan bersama.

Rasulullah Muhammmad saw. Pernah mengatakan bahwa sebagian besar rezeki manusia diperoleh dari aktivitas perdagangan. Hal ini disabdakan beliau dalam hadis yang diriwayatkan oleh Ibrahim Al-Harabi, "tis'ah al-asyari ar-rizqi minat tijjarah" artinya berdaganglah kamu, sebab lebih dari sepuluh bagian penghidupan, sembilan diantaranya dihasilkan dari berdagang. ${ }^{38}$

Pekerjaan berdagang/jual beli adalah sebagian dari pekerjaan bisnis. Kebanyakan masyarakat kita jika mereka berdagang, selalu ingin mencari laba besar. Jika ini yang menjadi tujuan usahanya, maka seringkali mereka menghalalkan berbagai cara untuk mencapai tujuan tersebut. Perilaku demikian sangat ditentang dalam ajaran Islam. Islam mengajarkan dalam sebuah hadits:

$$
\text { رحم الله رجلا سمحا اذ اباع واذا اشترى واذا اقتضى. رواه البخا رى }
$$

Artinya: "Allah mengasihi orang yang bermurah hati waktu menjual, waktu membeli, dan waktu menagih piutang".

Seorang muslim bila menjual barang, harus dengan senang hati, gembira, ikhlas, dan memberikan kesan baik terhadap pembeli. Begitu pula bila seorang muslim membeli barang, tidak membuat kesal si penjual, usahakan agar terjadi transaksi secara harmonis, suka sama suka, tidak bersitegang dengan penjual. Dalam hal menagih piutang, juga ada ajaran-ajaran yang bernilai sangat tinggi dalam Islam, jangan menekan, menghina, memeras, memaksa orang yang berutang. ${ }^{39}$

Konsep jual beli dalam Islam diharapkan menjadi cikal bakal dari sebuah sistem pasar yang tepat dan sesuai dengan alam bisnis. Sistem pasar yang tepat akan menciptakan sistem perekonomian yang tepat pula. Maka, jika kita ingin

${ }^{37}$ Basu Swastha, Manajemen Penjualan (Yogyakarta: BPFE Yogyakarta, 2010), 129.

${ }^{38}$ Ahmad Darbi and Siti Fariza, "Analisis Penjulan Rempeyek Jangkrik Perspektif Ekonomi Islam," Hukum Islam 15, no. 2 (2015): 270-285.

${ }^{39}$ Susi Widiasari, "Perilaku Pedagang Grosir Ditinjau Dari Etika Bisnis Islam," Al-Hikmah: Jurnal Kependidikan Dan Syariah 8, no. 2 (2020).

JAMMIAH (Jurnal Ilmiah Mahasiswa Ekonomi Syariah), Volume 1, Nomor 2, September 2021 
menciptakan suatu sistem perekonomian yang tepat, kita harus membangun suatu sistem jual beli yang sesuai dengan kaidah syariah Islam yang dapat melahirkan khalifah-khalifah yang tangguh di muka bumi ini. Hal tersebut dapat tercipta dengan adanya kerjasama antara seluruh elemen yang ada di pasar, yang disertai dengan kerja keras, kejujuran dan mampu melihat peluang yang tepat dalam membangun bisnis yang dapat berkembang dengan pesat. ${ }^{40}$

Dalam transaksi jual beli boleh terjadi kelalaian, baik ketika akad berlangsung maupun disaat-saat penyerahaan barang oleh penjual dan penyerahan harga (uang) oleh pembeli. Untuk setiap kelalaian itu ada risiko yang harus ditanggung oleh pihak yang lalai. Bentuk-bentuk kelalaian dalam jual beli itu, menurut para pakar fiqh, diantaranya adalah barang yang dijual bukan milik penjual (barang itu sebagai titipan [al-wadi'ah] atau jaminan utang di tangan penjual [ar-rahn] atau barang itu adalah barang hasil curian), atau menurut perjanjian barang harus diserahkan ke rumah pembeli pada waktu tertentu, tetapi tidak diantarkan atau tidak tepat waktu, atau barang itu rusak dalam perjalanan, atau barang yang diserahkan itu tidak sesuai dengan contoh yang disetujui. Dalam kasus-kasus seperti ini resiko adalah ganti rugi dari pihak yang lalai.

Ganti rugi dalam akad istilah fiqh disebut dengan adh-dhaman, yang secara harfiah boleh berarti jaminan atau tanggungan. Para pakar fiqh mengatakan bahwa adh-dhamanadakalanya berbentuk barang dan adakalanya berbentuk uang. Pentingnya adh-dhamanjual beli adalah agar dalam jual beli itu tidak terjadi perselisihan terhadap akad yang telah disetujui kedua belah pihak. Segala bentuk tindakan yang merugikan kedua belah pihak, baik terjadi sebelum maupun sesudah akad, menurut para ulama figh, harus ditanggung resikonya oleh pihak yang menimbulkan kerugian. ${ }^{41}$

\section{E. Perbandingan Penelitian Terdahulu}

Penelitian tentang Sistem Penjualan di perusahaan memang sudah banyak dilakukan oleh peneliti-peneliti sebelumnya seperti yang dilakukan oleh Shobirin ${ }^{42}$, Hasil dari penelitian menunjukan apabila dalam berbisnis melakukan jual beli sesuai dengan ajaran islam dan hukum-hukum islam, maka hasil bisnis yang dilakukan akan berjalan dengan baik dan mendapatkan berbagai hikmah. Perbedaan dengan

${ }^{40}$ Rudy Haryanto, "Sistem Ekonomi (Kajian Komparatif Antara Sistem Ekonomi Kapitalis Dan Islam)," Al-Ihkam: Jurnal Hukum dan Pranata Sosial 3, no. 1 (2019): 63-80.

${ }^{41}$ Haroen Nasrun, Fiqh Muamalah, 2nd ed. (Jakarta: Gaya Media Pratama, 2007), 121.

${ }^{42}$ Shobirin Shobirin, "Jual Beli Dalam Pandangan Islam," BISNIS: Jurnal Bisnis dan Manajemen Islam 3, no. 2 (2016): 239-261.

JAMMIAH (Jurnal Ilmiah Mahasiswa Ekonomi Syariah), Volume 1, Nomor 2, September 2021 
penelitian sekarang adalah mengkaji sistem penjualan yang dilakukan perusahan tanpa mengkaji sistem pembeliannya.

Selanjutnya penelitian yang dilakukan oleh Siti Anggraeni, Ina Rayana, Sarah Rahmalia Rahayu dan Annisa Julia Kirani ${ }^{43}$, Hasil penelitian menunjukan jika sistem penjualan barang di toko menggunakan sistem komputerisasi, maka proses penjualan barang dapat berjalan dengan cepat dan lebih akurat dibanding dengan cara manual, hal ini diakibatkan karena mudahnya mengakses informasi data barang melalui sistem komputerisasi. Perbedaan dengan penelitian sekarang adalah sistem penjualan yang diperuntukan untuk distributor atau perusahaan yang membutuhkan barang atau produk untuk diproses kembali, sedangkan penelitian sebelumnya mengkaji sistem penjualan barang atau produk siap jual untuk dikonsumsi.

Selanjutnya penelitian yang dilakukan oleh Zainal Arifin ${ }^{44}$, Hasil penelitian menunjukan bahwa program aplikasi manajemen data akuntansi memberikan kemudahan proses kerja karyawan bagian keuangan, memberikan pelayanan informasi atau pencarian data serta pelaporan keuangan perusahaan pada saat dibutuhkan secara cepat, tepat dan akurat serta dijadikan sebagai bahan evaluasi untuk meningkatkan kualitas Sumber Daya Manusia (SDM) bagian keuangan dalam penerapan dan penguasaan teknologi komputer yang kian pesat. Perbedaan dengan penelitian sekarang adalah sistem penjualan yang mengkaji tentang kemudahankemudahan dalam melakukan sistem penjualan secara tunai dan penjualan secara kredit dengan langkah-langkah yang dilakukan tidak menggunakan aplikasi atau secara manual.

\section{HASIL DAN PEMBAHASAN}

\section{A.Sistem Penjualan Di PT. Hae Indo Chemical Cikopo Purwakarta}

Sistem penjualan merupakan salah satu kegiatan yang sangat penting bagi setiap perusahaan, oleh karena itu diperlakukan suatu sistem yang efektif dan efisien untuk membantu peningkatan dan kemajuan perusahaan. Sistem penjualan bertujuan untuk menaikkan laba dan penerimaan kas bertambah sehingga perusahaan akan mendapatkan keuntungan dengan mengurangi kerugian. Sistem penjualan yang dilakukan di PT. Hae Indo Chemical Cikopo Purwakarta berbeda dengan sistem penjualan di perusahaan-perusahaan lain, karena perusahaan ini menjual produk atau barang setengah jadi yang harus diolah atau diproduksi kembali menjadi produk

${ }^{43}$ Siti Anggraeni and Ina Rayana, "Analisis Dan Perancangan Sistem Penjualan Untuk Meningkatkan Kualitas Pelayanan Terhadap Pelanggan Dengan Perbaikan Sistem Akuntansi Penjualan," JASa (Jurnal Akuntansi, Audit dan Sistem Informasi Akuntansi) 1, no. 1 (2017): 60-69.

${ }^{44}$ Zainal Arifin, "Rancang Bangun Sistem Informasi Manajemen Akuntansi Penjualan Pada Perusahaan PT. Purana Parasindo," Informatika Mulawarman: Jurnal Ilmiah Ilmu Komputer 7, no. 1 (2016): 12-22.

JAMMIAH (Jurnal Ilmiah Mahasiswa Ekonomi Syariah), Volume 1, Nomor 2, September 2021 
jadi. Yang artinya produk atau barang ini tidak bisa diperjual belikan kepada sembarang orang atau perorangan, dan alasan perusahaan mendirikan PT. Hae Indo Chemical Cikopo Purwakarta yang bergerak dibidang kimia dengan memproduksi bahan baku yang berjenis PS (Polystyrene) untuk dijadikan produk setengah jadi yang disebut dengan biji plastik adalah untuk mengurangi persaingan yang dihadapi oleh kebanyakan perusahaan, karena perusahaan yang bergerak dibidang kimia yang memproduksi biji plastik yang berjenis PS (Polystyrene) ini masih terbilang sangat jarang ditemui. Karena bahan baku yang digunakan biasanya bukan untuk perusahaan yang menyediakan produk untuk dikonsumsi atau dimakan.

Gambar 3.1

Contoh gambar pada bahan baku jenis PS (Polystyrene) Transparant cacahan.

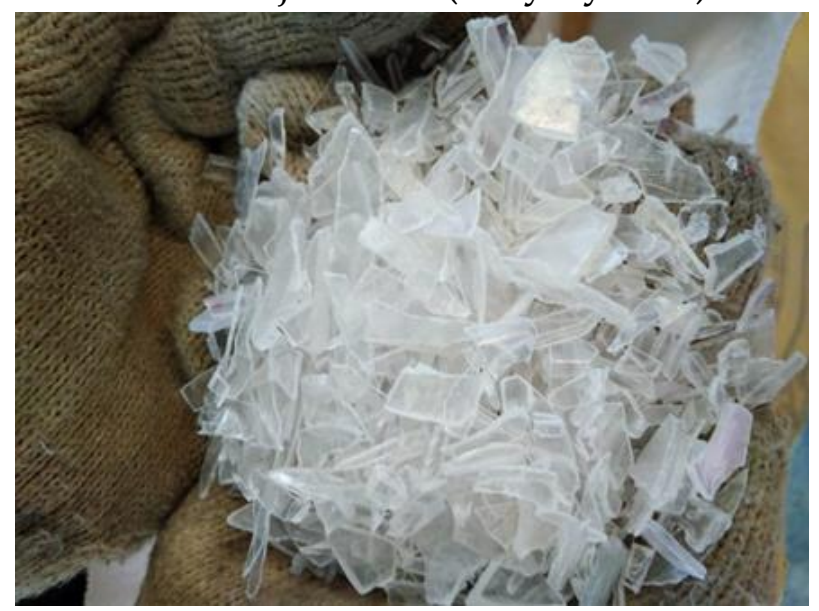

Gambar 3.2

Contoh gambar pada hasil produk biji plastik yang berjenis PS (Polysterene) $A$ Transparant White.

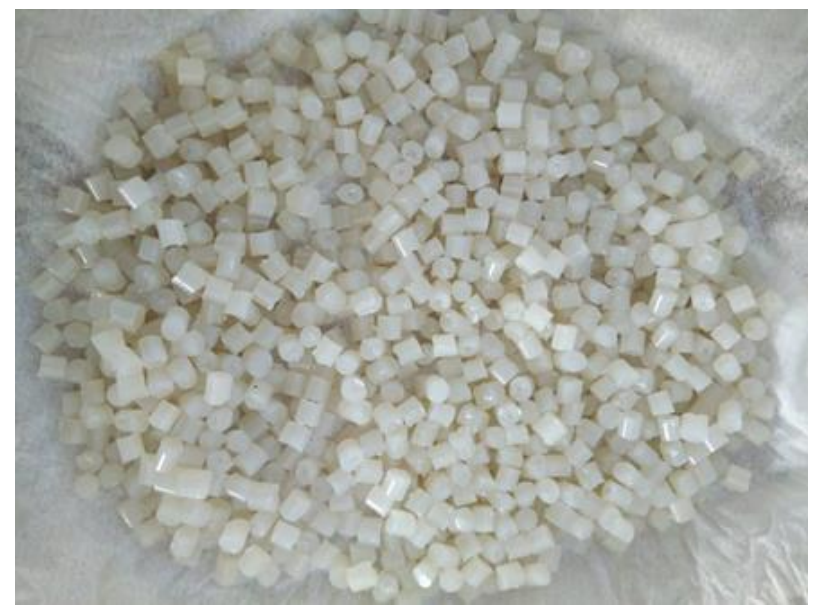

Sistem penjualan yang digunakan di PT. Hae Indo Chemical Cikopo Purwakarta saat ini yaitu sistem penjualan secara tunai dan sistem penjualan secara kredit. Dalam pandangan islam sistem penjualan yang dilakukan di PT. Hae Indo Chemical JAMMIAH (Jurnal Ilmiah Mahasiswa Ekonomi Syariah), Volume 1, Nomor 2, September 2021 
Cikopo Purwakarta menggunakan sistem penjualan Salam dan Taqsith. Dalam sistem penjualan yang diterapkan oleh PT. Hae Indo Chemical Cikopo Purwakarta menggunakan sistem penjualan secara offline atau manual dengan sistem yang masih terbatas. Hal ini dikarenakan PT. Hae Indo Chemical Cikopo Purwakarta merupakan perusahaan yang masih terbilang muda dan sangat baru, karena perusahaan ini baru berjalan selama 2 tahun. Adapun proses-proses sistem penjualan di PT. Hae Indo Chemical Cikopo Purwakarta adalah sebagai berikut :

\section{Sistem Penjualan Tunai}

Sistem penjualan tunai adalah sistem yang menjalankan proses penjualan dengan cara mewajibkan pembeli melakukan pembayaran harga barang lebih dahulu sebelum barang diserahkan oleh perusahaan kepada pembeli ${ }^{45}$. Sedangkan dalam islam sistem penjulan Salam adalah akad jual beli barang pesanan diantara pembeli dengan penjual. Spesifikasi dan harga barang pesanan harus sudah disepakati di awal akad, sedangkan pembayaran dilakukan di muka secara penuh atau tunai ${ }^{46}$. Setelah uang diterima oleh perusahaan, barang kemudian diserahkan atau dikirim kepada pembeli dan transaksi penjualan tunai kemudian dicatat oleh perusahaan. Bagian penjualan akan melakukan pemeriksaan di gudang terhadap jumlah yang diinginkan oleh pembeli tersebut apakah dapat dipenuhi sesuai dengan jumlah yang tersedia di gudang. Apabila dapat dipenuhi, maka bagian penjualan akan mengirimkan Proforma Invoice (PI) yang menjadi dasar bagi pihak pembeli untuk melakukan pembayaran kepada PT. Hae Indo Chemical Cikopo Purwakarta ke bank yang telah tertera pada Proforma Invoice (PI). Setelah diinformasikan bahwa pembayaran telah dilakukan oleh pembeli, maka bagian keuangan akan memeriksa apakah benar telah menerima sejumlah uang sesuai dengan kesepakatan kedua belah pihak. Setelah itu, maka pengiriman akan dilakukan dengan segera.

Adapun dokumen-dokumen yang digunakan pada sistem penjualan tunai adalah sebagai berikut :

a. Proforma Invoice (PI)

Proforma invoice (PI) merupakan faktur yang disiapkan oleh supplier sebelum menyediakan barang atau jasa. Proforma invoice (PI) ini nantinya akan dikirim ke customer sebelum mereka menerima produk. Fungsi dari proforma invoice diantaranya untuk memberikan layanan kepada pembeli atas transaksi yang dilakukan. Selain itu memungkinkan pembeli dalam memperkiraan biaya transaksi yang harus dibayar untuk produk yang dibeli, biaya pengiriman dan

${ }^{45}$ Ika Mary Pasaribu, “Tinjauan Tentang Sistem Penjualan Aluminium Ingot Pada Pt (Persero) Indonesia Asahan Aluminium (Inalum) Kuala Tanjung," Jurnal Ilmiah Dunia Ilmu 4, no. 1 (2018).

${ }^{46}$ Saprida Saprida, "Akad Salam Dalam Transaksi Jual Beli," Mizan: Journal of Islamic Law 4, no. 1 (2018).

JAMMIAH (Jurnal Ilmiah Mahasiswa Ekonomi Syariah), Volume 1, Nomor 2, September 2021

http://journal.sties-purwakarta.ac.id/index.php/jammiah/

ISSN: 2797-040X (Media Online) 2797-197X (Media Cetak) 
biaya pemrosesan. Dalam proses penjualan ini, setelah pihak perusahaan telah menyetujui dan mengetahui berapa banyak produk yang akan dijual, maka selanjutnya pihak perusahaan akan membuat Proforma Invoice (PI) untuk pihak pembeli.

b. Purchase Order (PO)

Purchase Order (PO) adalah dokumen yang berisi permintaan atas kebutuhan stok barang dan dikirim dari pihak pembeli kepada pemasok. Setelah pembeli telah menerima PI maka selanjutnya, pembeli akan mengirimkan Purchase Order (PO) yang berisikan nama perusahaan, tanggal pemesanan, jenis produk yang dipesan, serta banyaknya produk yang diinginkan. Selain itu, tercantum juga jumlah biaya yang akan dibayarkan dan transportasi pengiriman yang ditentukan dan sistem pembayaran yang digunakan juga akan tercantum dalam Purchase Order (PO) tata cara pembayaran yang diinginkan. (purchase order terlampir).

\section{Sistem Penjualan Kredit}

Sistem penjualan kredit adalah sistem penjualan yang dilaksanakan oleh perusahaan dengan cara mengirimkan barang sesuai dengan pesanan yang diterima dari pembeli dan untuk jangka waktu tertentu perusahaan yang mempunyai tagihan kepada pembeli tersebut ${ }^{47}$. Sedangkan dalam islam sistem penjulan Taqsith adalah adalah jual beli yang pembayarannya dicicil sampai waktu yang ditentukan ${ }^{48}$. Sistem penjualan kredit pada PT. Hae Indo Chemical Cikopo Purwakarta sangat sering dilakukan oleh setiap pembeli yang ingin membeli produk dan kebanyakan yang ingin menggunakan sistem pembelian kredit adalah sebuah perusahaan besar yang dapat secara terus-menerus memproduksi lanjut produk biji plastik yang berjenis PS (Polystyerene) dari PT. Hae Indo Chemical Cikopo Purwakarta. Dalam sistem penjualan kredit akan memberikan proses penjualan mulai dari kesepakatan untuk membuat kontrak antara kedua belah pihak, menyusun segala dokumen-dokumen yang menjadi salah satu hal penting dalam sistem penjualan kredit sampai kepada pembayaran harga final yang akan menimbulkan kekurangan dan kelebihan dari selisih harga Proforma Invoice dan Final Invoice.

Adapun dokumen-dokumen yang digunakan pada sistem penjualan kredit adalah sebagai berikut :

a) Surat Perjanjian Jual Beli Biji Plastik yang berjenis PS (Polystyrene)

${ }^{47}$ Asep Ririh Riswaya, "Sistem Penjualan Tunai Dan Kredit Property Di PT Sanggraha Property," Jurnal Computech E Bisnis 7, no. 2 (2013): 106-116.

${ }^{48}$ Misbakhul Khaer and Ratna Nurhayati, "Jual Beli Taqsith (Kredit) Dalam Perspektif Hukum Ekonomi Islam," AL MAQASHIDI 2, no. 1 (2019): 99-110.

JAMMIAH (Jurnal Ilmiah Mahasiswa Ekonomi Syariah), Volume 1, Nomor 2, September 2021 
Surat perjanjian jual beli biji plastik yang berjenis PS (Polystyrene) adalah surat perjanjian untuk melakukan pembelian secara kredit atau kontrak yang disepakati oleh kedua belah pihak, Pembeli dan Penjual ${ }^{49}$. Surat perjanjian yang telah dipersiapkan sesuai dengan ketentuan oleh perusahaan, maka akan dikirim kepada pembeli. Setelah surat diterima oleh pihak pembeli, pihak pembeli akan melakukan pemeriksaan dan apabila menyetujui surat tersebut, maka akan dilakukan penandatanganan di atas materai 6000 oleh kedua belah pihak. Namun sebaliknya apabila pembeli tidak menyetujui surat perjanjian kerjasama yang telah diterima, maka akan dilakukan negosiasi.

b) Provisional Invoice atau Invoice

Provisional Invoice atau Invoice adalah faktur yang diberikan kepada pembeli sesuai dengan harga pembelian yang disetujui ${ }^{50}$. Dengan kata lain, Provisional Invoice atau Invoice adalah faktur pembayaran yang berdasarkan harga sementara. Fungsi Provisional Invoice atau Invoice adalah untuk pengumpulan data mengenai barang atau produk yang sudah keluar yang dibeli oleh pidak pembeli daaaaan sebagai informasi tagihan yang harus dibayar. Dimana setelah harga final keluar, maka akan dapat selisih antara faktur sementara dengan faktur final apakah ada kekurangan dan kelebihan pembayaran.

c) Delivery Order (DO) atau surat jalan

\section{Gambar 3.3}

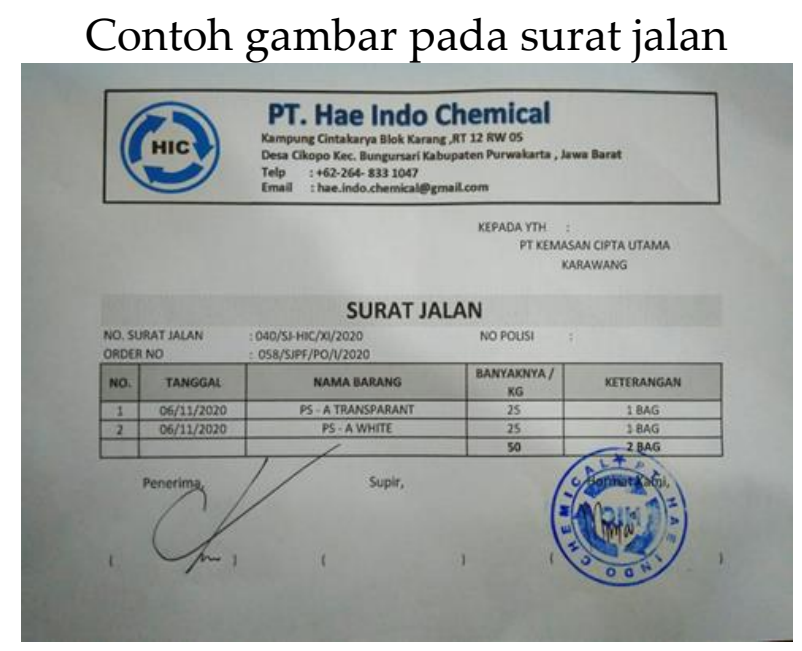

Setelah Provisional Invoice atau Invoice, dokumen yang harus dilengkapi dalam penjualan adalah Delivery Order (DO) atau surat jalan. Delivery Order (DO) atau surat jalan adalah sebagai bukti penyerahan barang yang diberikan kepada transportasi

${ }^{49}$ Siti Mujiatun, "Jual Beli Dalam Perspektif Islam: Salam Dan Istisna'," Jurnal Riset Akuntansi dan Bisnis 13, no. 2 (2014).

${ }^{50}$ Pasaribu, “Tinjauan Tentang Sistem Penjualan Aluminium Ingot Pada Pt (Persero) Indonesia Asahan Aluminium (Inalum) Kuala Tanjung."

JAMMIAH (Jurnal Ilmiah Mahasiswa Ekonomi Syariah), Volume 1, Nomor 2, September 2021 
pembeli apabila pembeli telah memberikan surat kuasa kepada transportasi untuk mengangkut barang. Fungsi dari Delivery Order atau surat jalan yaitu sebagai bentuk keterangan resmi terhadap pembelian barang dari pihak penjual kepada pidak pembeli. Delivery Order atau surat jalan berisikan nama tempat biji plastik disimpan, nama perusahaan yang membeli biji plastik, tanggal pengiriman biji plastik, nomor Delivery Order serta nomor kontrak.

d) Packing List

Packing List adalah suatu data yang akan dikirim yang terdiri dari berapa banyak produk yang dipesan ${ }^{51}$, banyak ikatan dan beratnya biji plastik yang berjenis PS (Polystyrene) serta jenis produk yang berbeda-beda. Tujuan dari Packing List adalah untuk memastikan agar tidak terjadi kesalahan dalam pengiriman dan disebut sebagai acuan untuk melakukan pemeriksaan di gudang. Setelah terdaftar rincian biji plastik yang berjenis PS (Polystyrene) per karung, maka ditotalkan seluruhnya.

e) Certificate Of Analysis

Certificate Of Analysis adalah salah satu dokumen yang penting dalam proses penjualan ${ }^{52}$. Certificate Of Analysis berfungsi sebagai analisis barang baik itu mulai dari spesifikasi barang hingga pembuktian kinerja suatu barang yang akan dikirim atau yang sering disebut sebagai parameter kualitas suatu produk. Certificate Of Analysis berisikan jenis komposisi dan kualitas Biji Plastik yang berjenis PS (Polystyrene) yang dibeli, lalu proses pengiriman dilakukan. Setelah dilakukan pengiriman, proses penjualan belum selesai. Dimana harga yang kedua belah pihak setujui dan telah dilakukan pembayaran adalah harga sementara yang pada akhirnya akan keluar harga final (Final Invoice), yakni harga yang disetujui oleh perusahaan selaku Penjual dengan Pembeli untuk penjualan biji plastik yang berjenis PS (Polystyrene) sampai ditempat tujuan pengiriman dan untuk periode tertentu. Selain itu, harga final juga akan menentukan apakah ada kelebihan atau kekurangan pembayaran terhadap biji plastik yang berjenis PS (Polystyrene) yang telah dikirimkan $^{53}$.

\section{KESIMPULAN}

Berdasarkan pengumpulan data yang diteliti oleh penulis mengenai sistem penjualan pada PT. Hae Indo Chemical Cikopo Purwakarta secara tunai dan kredit dilakukan dengan efektif dan berjalan dengan sangat baik dalam melakukan proses

${ }^{51}$ Aditya W Utama, “Analisis Faktor-Faktor Yang Mempengaruhi Penundaan Pengiriman Barang Melalui Jalur Laut," jurnal citra widya edukasi 10, no. 2 (2018): 97-108.

52 Siti Ulfah Fauziah et al., "Sistem Pendukung Keputusan Penyedia Dokumen Dalam Pengajuan Sertifikasi Halal Menurut LPPOM-MUI," Jurnal Teknologi Industri Pertanian 27, no. 3 (2017).

${ }_{53}$ PT. Hae Indo Chemical, Company Profile (Jakarta: PT. Hae Indo Chemical, 2018), 6.

JAMMIAH (Jurnal Ilmiah Mahasiswa Ekonomi Syariah), Volume 1, Nomor 2, September 2021 
penjualan produk setengah jadi. Adapun dokumen-dokumen yang digunakan pada sistem penjualan tunai diantaranya : Proforma invoice (PI), yang merupakan faktur yang disiapkan oleh supplier sebelum menyediakan barang atau jasa. Dan Purchase Order (PO), yang merupakan dokumen yang berisi permintaan atas kebutuhan stok barang dan dikirim dari pihak pembeli kepada pemasok. Selanjutnya penjualan secara kredit, dokumen-dokumen yang digunakan pada sistem penjualan kredit diantaranya : Surat Perjanjian Jual Beli Biji Plastik yang berjenis PS (Polystyrene), Provisional Invoice atau Invoice, Delivery Order (DO) atau surat jalan, Packing List, Certificate Of Analysis, dan setelah dilakukan pengiriman, proses penjualan belum selesai. Dimana harga yang kedua belah pihak setujui dan telah dilakukan pembayaran adalah harga sementara yang pada akhirnya akan keluar harga final (Final Invoice). Dengan adanya dokumen-dokumen tersebut, maka perusahaan akan berjalan dengan lebih baik sesuai dengan alurnya.

\section{DAFTAR PUSTAKA}

Aini, Yenny Kuratul, and Wadhan Wadhan. "Pengaruh Strategi Bauran Pemasaran Terhadap Peningkatan Loyalitas Nasabah Pada BPRS Bhakti Sumekar Kantor Cabang Pamekasan." IQTISHADIA: Jurnal Ekonomi dan Perbankan Syariah 3, no. 2 (2016): 278-289.

Anggraeni, Siti, and Ina Rayana. "Analisis Dan Perancangan Sistem Penjualan Untuk Meningkatkan Kualitas Pelayanan Terhadap Pelanggan Dengan Perbaikan Sistem Akuntansi Penjualan." JASa (Jurnal Akuntansi, Audit dan Sistem Informasi Akuntansi) 1, no. 1 (2017): 60-69.

Angipora, Marius P. Dasar-Dasar Pemasaran. Jakarta: PT. Raja Grafindo Persada, 2002. Arifin, Ali. "Seni Menjual (Perspektif Bisnis, Ide-Ide Penjualan Serta Strategi Pemasaran)." Penerbit Andi, Yogyakarta (2005).

Arifin, Zainal. "Rancang Bangun Sistem Informasi Manajemen Akuntansi Penjualan Pada Perusahaan PT. Purana Parasindo." Informatika Mulawarman: Jurnal Ilmiah Ilmu Komputer 7, no. 1 (2016): 12-22.

Aziz, Abdul. Ekonomi Islam: Analisis Mikro Dan Makro. Tangerang: Graha Ilmu, 2008.

Cahyono, Heru. "Konsep Pasar Syariah Dalam Perspektif Etika Bisnis Islam." Ecobankers: Journal of Economy and Banking 1, no. 2 (2020): 14-27.

Cahyono, Susanti Aprillia, Bramantya Bramantya, and Ryan Sutanto. "Perancangan

Promosi Amelia Cake \& Bakery Di Surabaya." Jurnal DKV Adiwarna 1, no. 6 (2015): 12.

JAMMIAH (Jurnal Ilmiah Mahasiswa Ekonomi Syariah), Volume 1, Nomor 2, September 2021 http://journal.sties-purwakarta.ac.id/index.php/jammiah/ ISSN: 2797-040X (Media Online) 2797-197X (Media Cetak) 
Darbi, Ahmad, and Siti Fariza. "Analisis Penjulan Rempeyek Jangkrik Perspektif Ekonomi Islam." Hukum Islam 15, no. 2 (2015): 270-285.

Daud, Rochmawati, and valeria mimosa Windana. "Pengembangan Sistem Informasi Akuntansi Penjualan Dan Penerimaan Kas Berbasis Komputer Pada Perusahaan Kecil Studi Kasus PT Trust Technology." JURNAL MANAJEMEN DAN BISNIS SRIWIJAYA 12 (2014): 17-28.

Fauziah, Siti Ulfah, Kudang Boro Seminar, Irman Hermadi, and Nugraha Edhi Suyatma. "Sistem Pendukung Keputusan Penyedia Dokumen Dalam Pengajuan Sertifikasi Halal Menurut LPPOM-MUI." Jurnal Teknologi Industri Pertanian 27, no. 3 (2017).

Haryanto, Rudy. "Sistem Ekonomi (Kajian Komparatif Antara Sistem Ekonomi Kapitalis Dan Islam)." Al-Ihkam: Jurnal Hukum dan Pranata Sosial 3, no. 1 (2019): 63-80.

Hayani, Nurahmi. "Manajemen Pemasaran Bagi Pendidikan Ekonomi." Pekanbaru: Suska Press, 2012.

Hendari, Henny, I Gusti Made Karmawan, and others. "Analisis Dan Perancangan Sistem Informasi Akuntansi Penjualan." PEKBIS (Jurnal Pendidikan Ekonomi Dan Bisnis) 1, no. 03 (2009).

Khaer, Misbakhul, and Ratna Nurhayati. “Jual Beli Taqsith (Kredit) Dalam Perspektif Hukum Ekonomi Islam." AL MAQASHIDI 2, no. 1 (2019): 99-110.

Kotler, Philip, and Kevin Lane Keller. Manajemen Pemasaran. Jilid 2 Ed. Jakarta: Erlangga, 2009.

Mujiatun, Siti. "Jual Beli Dalam Perspektif Islam: Salam Dan Istisna'." Jurnal Riset Akuntansi dan Bisnis 13, no. 2 (2014).

Nasrun, Haroen. Figh Muamalah. 2nd ed. Jakarta: Gaya Media Pratama, 2007.

Natadiwirya, Muhandis. Etika Bisnis Islam. Jakarta: Granada Press, 2007.

Pasaribu, Ika Mary. “Tinjauan Tentang Sistem Penjualan Aluminium Ingot Pada Pt (Persero) Indonesia Asahan Aluminium (Inalum) Kuala Tanjung." Jurnal Ilmiah Dunia Ilmu 4, no. 1 (2018).

PT. Hae Indo Chemical. Company Profile. Jakarta: PT. Hae Indo Chemical, 2018.

Rahman, Arif. Strategi Dahsyat Marketing Mix for Small Business. Jakarta: Transmedia Pustaka, 2010.

Rahmi, Ain. "Mekanisme Pasar Dalam Islam." Jurnal Ekonomi Bisnis dan Kewirausahaan

JAMMIAH (Jurnal Ilmiah Mahasiswa Ekonomi Syariah), Volume 1, Nomor 2, September 2021 http://journal.sties-purwakarta.ac.id/index.php/jammiah/ ISSN: 2797-040X (Media Online) 2797-197X (Media Cetak) 
Vol. 4, No (2015).

Rangkuti, Freddy. Strategi Promosi Yang Kreatif \& Analisis Kasus Integrated Marketing Communication. Jakarta: Gramedia Pustaka Utama, 2009.

RI, Departemen Agama. Al-Qur'an Dan Terjemahnya. Jakarta: PT. Sygma Examedia Arkanlemma, 2009.

Riswaya, Asep Ririh. "Sistem Penjualan Tunai Dan Kredit Property Di PT Sanggraha Property." Jurnal Computech \& Bisnis 7, no. 2 (2013): 106-116.

Saprida, Saprida. “Akad Salam Dalam Transaksi Jual Beli." Mizan: Journal of Islamic Law 4, no. 1 (2018).

Shobirin, Shobirin. "Jual Beli Dalam Pandangan Islam." BISNIS: Jurnal Bisnis dan Manajemen Islam 3, no. 2 (2016): 239-261.

Soenarjo. Al-Qur'an Dan Terjemahnya. Jakarta: Serajaya Sentra, 1987.

Sopiah, Syihabudhin. Manajemen Bisnis Ritel. Yogyakarta: Penerbit Andi, 2008.

Stanton, William J. Prinsip Pemasaran. Jakarta: Erlangga, 2001.

Susiawati, Wati. “Jual Beli Dan Dalam Konteks Kekinian.” Jurnal Ekonomi Islam 8, no. 02 (2017): 171-184.

Suyanto, Muhammad. Muhammad Business Strategy and Ethics. Yogyakarta: Andi Offset, 2008.

Swastha, Basu. Manajemen Penjualan. Yogyakarta: BPFE Yogyakarta, 2010.

Tantri, Francis, and Thamrin Abdullah. Manajemen Pemasaran. Jakarta: PT. Raja Grafindo Persada, 2019.

Tjiptono, Fandy. Strategi Pemasaran. Yogyakarta: Andi, 2000.

Utama, Aditya W. "Analisis Faktor-Faktor Yang Mempengaruhi Penundaan Pengiriman Barang Melalui Jalur Laut." jurnal citra widya edukasi 10, no. 2 (2018): 97-108.

Wahjono, Sentot Imam. Manajemen Pemasaran Bank. Yogyakarta: Graha Ilmu, 2010.

Wardani, Winda Kusuma. “Analisis Sistem Dan Prosedur Penjualan Dan Penerimaan Kas Dalam Upaya Meningkatkan Pengendalian Intern Perusahaan (Studi Kasus Pada Pt Anugerah Cendrawasih Sakti Motor Malang)." Jurnal Administrasi Bisnis 12, no. 1 (2014).

Widiasari, Susi. "Perilaku Pedagang Grosir Ditinjau Dari Etika Bisnis Islam." AlHikmah: Jurnal Kependidikan Dan Syariah 8, no. 2 (2020).

JAMMIAH (Jurnal Ilmiah Mahasiswa Ekonomi Syariah), Volume 1, Nomor 2, September 2021 http://journal.sties-purwakarta.ac.id/index.php/jammiah/ ISSN: 2797-040X (Media Online) 2797-197X (Media Cetak) 
Zulkarnain. Ilmu Menjual (Pendekatan Teoritis \& Kecakapan Menjual). 1st ed. Yogyakarta: Graha Ilmu, 2012. 